\title{
Pulsed Electromagnetic Field and Pulsed Ultrasound Increases Chondrogenesis through HSP70 Overexpression in Rat Articular Cartilage
}

\author{
Hyun-Mo Koo, PT, $\mathrm{PhD}^{\dagger}$
}

Department of Physical Therapy, College of Science, Kyungsung University

\section{흰쥐의 관절연골에서 맥동전자장과 맥동초음파가 HSP70의 과발현을 통한 연골형성에 미치는 영향 구현모 ${ }^{\dagger}$ \\ 경성대학교 이과대학 물리치료학과}

Received: January 17, 2013 / Revised: February 13, 2013 / Accepted: February 13, 2013

(c) 2013 Journal of the Korean Society of Physical Medicine

\section{| 국문초록 |}

연구목적: 본 연구는 흰쥐를 대상으로 정강뼈의 관절 연골에 적용한 맥동전자장과 맥동초음파가 HSP70(Heat shock protein 70)의 발현을 통한 연골 형성에 미치는 영향 을 알아보고자 실시하였다.

연구방법: 36 마리의 $200 \sim 250 \mathrm{~g}$ 의 Sprague-Dawley 흰 쥐를 대조군, 맥동전자장 적용군, 맥동초음파 적용군으 로 각 집단별로 12 마리씩 무작위 배정하여 실험을 진행 하였다. 맥동전자장은 $27.12 \mathrm{MHz}$ 의 주파수, 5 가우스의 강도, $450 \mathrm{~W}$ 의 출력으로 10 분간 적용하였고, 맥동초음파 는 $20 \%$ 의 맥동비, $1 \mathrm{MHz}$ 의 주파수, $1.5 \mathrm{~W} / \mathrm{cm}^{2}$ 의 강도로 10 분간 적용하였다.

연구결 과: 맥동전자장 적용군과 맥동초음파 적용군 의 관절연골 조직에서 유의한 수준의 HSP70 발현량을 나 타냈다. 또한 맥동전자장 적용군과 맥동초음파 적용군 에서는 Akt, Erk1, CREB의 높은 활성도를 나타내었고, 맥

†교신저자 : hmkoo@ks.ac.kr

This is an Open Access article distributed under the terms of the Creative Commons Attribution Non-Commercial License (http://creativecommons.org/licenses/by-nc/3.0) which permits unrestricted non-commercial use, distribution, and reproduction in any medium, provided the original work is properly cited.
동초음파 적용군에 비해서 맥동전자장 적용군의 더 높 은 수준의 활성도를 보였다.

결 론: 맥동전자장과 맥동초음파는 HSP70의 과발현을 유발하고, 이를 통해 연골형성을 증가시키는 것으로 나 타나, 향후 관절연골의 손상에 대한 임상적 적용을 위한 추가적인 연구가 진행되어야 할 것으로 생각된다.

주제어: 관절연골, $\operatorname{HSP} 70$, 맥동초음파, 맥동전자장

\section{Introduction}

Osteoarthritis, the most common form of arthritis, has a very high prevalence among middle-aged and elderly people and the disease is responsible for substantial direct and indirect socioeconomic costs and the treatment options are few and unsatisfactory (Thamsborg et al., 2005). Osteoarthritis is usually accompanied by focal destruction of the articular cartilage lining of synovial joints, plus extensive subchondral bone remodeling and possible bone necrosis (Nguyen and Marks, 2002).

Articular cartilage of movable joints is a semi- 
transparent, specialized connective tissue composed of chondrocytes that form cellular compartments, and has the unique ability to allow for free joint movement, with reduced friction and abrasion. It also plays a role in absorbing shock to joints in daily life (Archer and Francis-West, 2003). These repeated stresses to the articular cartilage frequently result in chronic degeneration in the long run, and ultimately the development of arthritis. However, the self-repair of articular cartilage is generally restricted under certain biological conditions (Hunziker, 2002). Thus, there is a notable importance for therapeutic strategies for the treatment of articular cartilage.

Recently a number of papers have appeared suggesting pulsed electromagnetic fields (PEMF) and therapeutic ultrasound as a technique for treatment of osteoarthrosis in which technique was applied one or a few times a day for up to a month (Korstjens et al., 2008). The mode of action of PEMF is based on creating small electrical fields in tissue and thereby promoting biological effects. Beneficial therapeutic effects on cells and tissues of PEMF have also been documented in increasing articular chondrocyte proliferation, extracellular matrix synthesis and proteoglycans content in cartilage tissue explants (Ciombor et al., 2003; Liu et al., 1997).

The therapeutic effects of low intensity ultrasound include the stimulation of physiological responses in injured regions, whereas high intensity ultrasound is applied to selectively destruct the tissue (ter Haar, 2007). The physiological effects of ultrasound in biological tissues may also include thermal and mechanical effects. Ultrasound also induces healing process, including angiogenesis, chondrogenesis, intramembranous ossification, and bone remodeling (Chan et al., 2010).

It has been reported that the synthesis of heat shock protein 70 (HSP70) which can be defined as HSP70 expression tends to be elevated in patients with osteoarthritis. It is also associated with the clinical progression of arthritis. HSP, a stress protein, is synthesized shortly after that cells are exposed to stress or a rapid rise in temperature (Kubo et al., 2001). Under autoimmune disease or arthritis conditions, its expression is increased, protects cells, and enhances cell viability. In particular, HSP70 shows the most profound response according to alterations in temperature, and contributes to the maintenance of homeostasis in the intracellular environment(lancaster and Febbraio, 2005).

Therefore, this study was to investigate the effects of PEMF and Pulsed Ultrasound (PUS) irradiation on HSP70 expression and its associated signal molecules in rat articular cartilage. This can help us to achieve a better understanding of the changes in articular cartilage during PEMF and PUS irradiation, with the possibility of finding molecules having much potential to be developed into therapeutic agents for arthritis.

\section{Materials and Methods}

\section{Experimental Animals}

I used 36 Sprague-Dawley rats (B.W. 200-250g) as experimental animals and housed them in standard cages $(20 \times 15 \times 45 \mathrm{~cm})$. The experimental animals were provided with sufficient feed and water during the experimental period. The housing room conditions were maintained as follows: $23 \pm 2^{\circ} \mathrm{C}$ temperature, $40-60 \%$ humidity, and 12 hours on/12hours off light/dark cycle, in order to standardize environmental influences. All the experiments were performed in accordance with protocols approved by the University of Daegu Animal Experiment Committee, based on the NIH Guidelines for the Care and Use of Laboratory Animals (National Institutes of Health, 1996). All 36 experimental animals were randomly divided into the control, PEMF and PUS applied groups and employed for each experiment described.

\section{Experimental procedure}

Animals were anesthetized with intraperitoneal injection and treated with PEMF and PUS, only the right knee was 
treated. PEMF was conducted with Diapulse (Diapulse Corp., America). The frequency of the electromagnetic field used in the present study was $27.12 \mathrm{MHz}$, and intensity of 5 gauss and a pulse output of $450 \mathrm{~W}$ for 10 minutes per day. Ultrasound was applied with SONOPULS 590(ENFAF NONIUS, Holland). During the sonication procedure, the ultrasound head was held stationary, approximately $2 \mathrm{~cm}$ from the target area under water. PUS group was applied at a frequency of $1 \mathrm{MHz}$, the intensity of $1.5 \mathrm{~W} / \mathrm{cm}^{2}$, the pulse rate of $20 \%$, and the duration of 10 minutes. The PEMF and PUS irradiation was performed once a day.

\section{Sampling for extraction of protein}

When euthanized, the animals were anesthetized with $2 \mathrm{ml} / \mathrm{kg}$ of $50 \%$ Zoletil and a $50 \%$ xylazine hydrochloride mixture. The articular cartilage was obtained $1 \mathrm{~cm}$ from the distal femur and proximal tibia in knee joint without soft tissue. After collection, the samples were washed twice and homogenized in the PBS. The homogenates were centrifuged for $10 \mathrm{~min}$ at $15,000 \mathrm{rpm}$ and $4^{\circ} \mathrm{C}$ and collected by removing the supernatant.

\section{Western blot analysis}

The obtained homogenates lysed with buffer $(137 \mathrm{mM}$ $\mathrm{NaCl}, 8.1 \mathrm{mM} \mathrm{Na} \mathrm{HPO}_{4}, 2.7 \mathrm{mM} \mathrm{KCl}, 1.5 \mathrm{mM} \mathrm{KH}_{2} \mathrm{PO}_{4}$, 2.5mM EDTA, $1 \mathrm{mM}$ dithiothreitol, $0.1 \mathrm{mM}$ PMSF, $10 \mu$ $\mathrm{g} / \mathrm{ml}$ leupeptin[pH7.5]) for $30 \mathrm{~min}$ on ice. The lysates were centrifuged for $10 \mathrm{~min}$ at $15,000 \mathrm{rpm}$ and $4{ }^{\circ} \mathrm{C}$, and the protein concentrations were determined as described previously (Bradford, 1976). Equal amounts of protein (40 $\mathrm{\mu g}$ ) were resolved by $10 \%$ sodium dodecyl sulfate-polyacrylamide gel electrophoresis (SDS-PAGE) and transferred to nitrocellulose membranes. The blots were washed with TBST (10mM Tris • $\mathrm{HCl}$ [pH 7.6], $150 \mathrm{mM} \mathrm{NaCl}, 0.05 \%$ Tween 20), blocked with 5\% skim milk for $1 \mathrm{~h}$, and incubated with the appropriate primary antibodies at the dilutions recommended by the suppliers. The membranes were washed, and the primary antibodies were detected with horseradish peroxidase-conjugated goat anti-rabbit IgG or goat-anti mouse IgG. The bands were then visualized via enhanced chemiluminescence (Amersham Pharmacia Biotech, Piscataway, NJ, USA).

\section{Statistical analysis}

The results are expressed as the mean \pm standard error (S.E.). All experiments were analyzed via analysis of variance, and some experiments were examined by comparing the treatment means with the controls using the BonferroniDunn test. The difference was considered statistically significant when $p<.05$.

\section{Results and Discussion}

In this study, we was to investigate the effects of PEMF and PUS irradiation on HSP 70 expression and its associated signal molecules in rat articular cartilage. The articular cartilage, in particular, maintains normal physical function regulated stress protein expression to support the stable state by inducing a variety of stimulations. Thus, abnormal expression of the protective protein in articular cartilage may induce osteoarthritis and pathological changes (Hunziker, 2002).

Commonly, physical therapies advocated for treating the symptoms of osteoarthritis include exercise and a wide variety of electrotherapeutic modalities. Huang et al. (1997) previously reported that the application of therapeutic ultrasound stimulated there pair of the articular tissue and prevented pathological progression. Recently have appeared suggesting PEMF as a technique for treatment of osteoarthrosis in which technique was applied. Jacobson et al. (2001). and Nicolakis et al. (2002) observed that PEMF stimulation was safe, reduced impairment in activities of daily life and improved knee function in patients with chronic knee pain due to arthrosis.

In this study, we confirmed the expression of HSP70 
in rat tibial articular cartilage after PEMF and PUS irradiation. Our results demonstrate that the PEMF and PUS groups showed significant increases in HSP70 expression compared to the control group $(\mathrm{p}<.05)$. The expression of HSP70 protein was increased in the PEMF and PUS groups. However, there were not significant differences between the two groups $(\mathrm{p}>.05)$ (Fig. 1).

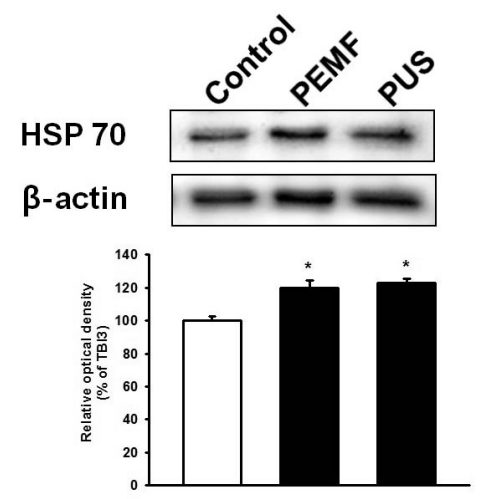

Fig. 1. The effect of PEMF and PUS on HSP70 expression.

HSP70 expression in patients with osteoarthritis tends to be elevated above normal, and is associated with the clinical progression of arthritis. HSP70 is rapidly synthesized when cells are exposed to a sudden rise in temperature. It functions to minimize cell injury by maintaining proper protein folding combined with degenerative enzyme proteins and by supporting intracellular homeostasis, including protein transport and synthesis (Sedlackova et al., 2009). Although HSP70 is spontaneously expressed under rapid-onset pathological conditions, it does not sufficiently protect against cell injury. Therefore, PEMF and PUS application is required to prevent the pathological progression of arthritis and promote the repair mechanism by maintaining HSP70 expression (Kubo et al., 2001).

In addition, the results of this study showed that PEMF and PUS application stimulated an increase in HSP70 expression and its associated molecular alterations in articular cartilage tissues. HSP70 functions as a molecular chaperone that promotes proteins and assembly, and membrane translocation is also related to cell cycle mediation and resistance to stress-induced cell death $(\mathrm{Li}$ et al., 2008). Moreover, HSP70 can be released into the extracellular space as an intracellular response to stress. This interacts with adjacent cells or, in some cases, enters the bloodstream and interacts with a variety of signal pathways (Kiang and Tsokos, 1998).

In this study, to confirm the effect of PEMF and PUS in chondrogenesis related signal molecules, the experiment for Akt, ERK, and CREB activation was performed. Akt, ERK, and CREB activation increased significantly after 10 minutes of application in the PEMF and PUS groups $(\mathrm{p}<.05)$. Moreover, there was a significant increase in Akt, ERK, and CREB activation for the PEMF and PUS groups, a significantly greater increase was found in the PEMF group compared to the PUS group $(\mathrm{p}<.05)$ (Fig. 2).

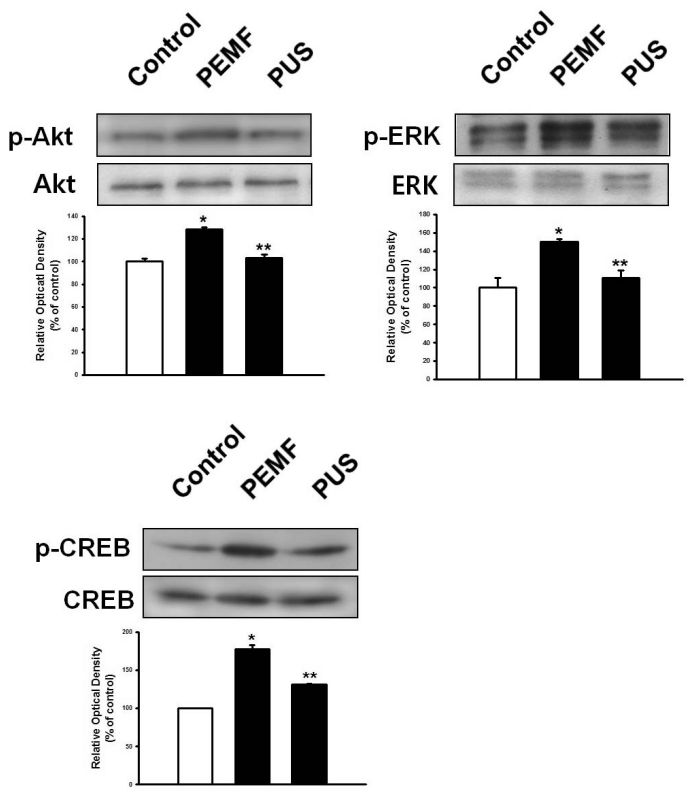

Fig. 2. The effect of PEMF and PUS on Akt, ERK, and CREB activation 
In particular, mild heat stress, associated with HSP70 expression, is assumed to positively regulate cell cycle progression and to induce the complex Ras signal pathway including the ERK1/2 pathway, PI3K/Akt pathway, and NADPH oxidase pathway (Calderwood et al., 2007). According to our results, the application of PEMF and PUS induced an increase in Akt and ERK activation. Akt signaling regulates cell proliferation, growth, and migration in many cell and tissue types (Park et al., 2005). Kita et al. (2008) demonstrated that Akt signaling functions a key role in chondrogenesis during endochondral bone formation. Additionally, mitogen activated protein kinases (MAPKs) are among the most extensive signaling pathways that are known to be involved in chondrocyte proliferation via signal transduction. This is crucial to the regulation of bone and cartilage development (Li et al., 2009). MAPKs include ERK1/2, JNKs, and p38 MAPK. The ERKs are activated by mitogenic stimuli, whereas the other MAPKs are more responsive to stress stimulation. In particular, HSP plays a protective role that involves the ERK pathway (Wang et al., 2009).

Our results suggest that PEMF and PUS influences chondrogenesis via HSP 70 overexpression in rat articular cartilage via involvement of Akt, Erk, and CREB. Although these results has some limitations which were performed in normal animal model and needed more clinical aspect for human, the present study will be useful to provide the evident clue that the biological effects of PEMF and PUS in the articular cartilage might exert a positive effect on intracellular metabolism as well as the stimulation of metabolic activation in the extracellular matrix. Moreover, these demonstrate not only the therapeutic mechanism of PEMF and PUS from a biological viewpoint, but also indicate the potential of PEMF and PUS as a practical method by which chondrogenesis can be increased in a variety of scaffolds used for tissue engineering and as a non-pharmacological and non-operative method for articular cartilage regeneration.

\section{Conclusion}

PEMF and PUS induced HSP 70 overexpression in rat articular cartilage and these results imply PEMF and PUS can influence chondrogenesis via involvement of Akt, Erk, and CREB, in the present study. These will be helpful to contribute the evidence that the effects of PEMF and PUS in the articular cartilage might exert a biological effect on intracellular metabolism as well as the stimulation of metabolic activation in the extracellular matrix. It is required to perform experiments in the various injured model and environment for support of evidence based practice.

\section{Acknowledgement}

This reasearch was supported by the Research Grant of Kyungsung University in 2012.

\section{Reference}

Archer CW, Francis-West P. The chondrocyte. Int J Biochem Cell Biol. 2003;35(4):401-4.

Bradford MM. A rapid and sensitive method for the quantitation of microgram quantities of protein utilizing the principle of protein-dye binding. Anal Biochem. 1976;72(1-2):248-54.

Calderwood SK, Mambula SS, Gray PJ Jr et al. Extracellular heat shock proteins in cell signaling. FEBS Lett. 2007;581(19):3689-94.

Chan YS, Hsu KY, Kuo CH et al. Using low-intensity pulsed ultrasound to improve muscle healing after laceration injury: an in vitro and in vivo study. Ultrasound Med Biol. 2010;36(5):743-51.

Ciombor D, Aaron RK, S Wang et al. Modification of osteoarthritis by pulsed electromagnetic field-a 
morphological study. Osteoarthritis Cartilage. 2003; 11(6):455-62.

Huang MH, Tsau JC, Ding $\mathrm{HJ}$ et al. The role of mucopolysaccharide induction in treatment of experimental osteoarthritis in rats by ultrasound. Kaohsiung J Med Sci. 1997;13(11):661-70.

Hunziker EB. Articular cartilagerepair: basic science and clinical progress. a review of the current status and prospects. Osteoarthritis Cartilage. 2002;10(6):432-63.

Jacobson JI, Gorman R, Yamanashi WS et al. Low-amplitude, extremely low frequency magnetic fields for the treatment of osteoarthritic knees: a double-blind clinical study. Altern Ther Health Med. 2001;7(5): 54-64.

Kiang JG, Tsokos GC. Heat shock protein 70 kDa: molecular biology, biochemistry, and physiology. Pharmacol Ther. 1998;80(2):183-201.

Kita K, Kimura T, Nakamura $\mathrm{N}$ et al. PI3K/Akt signalling as a key regulatory pathway for chondrocyte terminal differentiation. Genes Cells. 2008;13(8):839-50.

Korstjens CM, van der Rijt RH, Albert GH et al. Low-intensity pulsed ultrasound affects human articular chondrocytes in vitro. Med Biol Eng Comput. 2008;46(12):1263-70.

Kubo T, Arai Y, Takahashi K et al. Expression of transduced HSP70 gene protects chondrocytes from stress. J Rheumatol. 2001;28(2):330-5.

Lancaster GI, Febbraio MA. Exosome-dependent trafficking of HSP70: a novel secretory pathway for cellular stress proteins. J Biol Chem. 2005;280(24):23349-55.

Li H, Zhang YY, Tan HW et al. Therapeutic effect of tripterine on adjuvant arthritis in rats. J Ethnopharmacol. 2008;118(3):479-84.

Li J, Zhao Z, Yang J et al. p38 MAPK mediated in compressive stress-induced chondrogenesis of rat bone marrow MSCs in 3D alginate scaffolds. J Cell Physiol. 2009;221(3):609-17.

Liu H, Lees P, Abbott J et al. Pulsed electromagnetic fields preserve proteoglycan composition of extracellular matrix in embryonic chick sternal cartilage. Biochim Biophys Acta, 1997;1336(2):303-14.

Nicolakis P, Kollmitzer J, Crevenna R et al. Pulsed magnetic field therapy for osteoarthritis of knee-a double-blind sham-controlled trial. Wien Klin Wochenschr. 2002;114(15-16):678-84.

National Institutes of Health. Guide for the care and use of laboratory animals. 8th ed. Washington D.C. The National Academies Press. 1996.

Nguyen JV, Marks R. Pulsed electromagnetic fields for treating osteoarthritis. Physiotherapy. 2002;88(3):458-70.

Park HG, Han SI, Oh SY et al. Cellular responses to mild heat stress. Cell Mol Life Sci. 2005;62(1):10-23.

Sedlackova L, Nguyen TT, Zlack D et al. Cell surface and relative mRNA expression of heat shock protein 70 in human synovial cells. Autoimmunity. 2009; 42(1)17-24.

ter Haar G. Therapeutic applications of ultrasound. Prog Biophys Mol Biol. 2007;93(1-3):111-29.

Thamsborg G, Florescu A, Oturai P et al. Treatment of knee osteoarthritis with pulsed electromagnetic fields: a randomized, double-blind, placebo-controlled study. Osteoarthritis and Cartilage. 2005;13(7):575-81.

Wang Z, Jin H, Li C et al. Heat shock protein 72 protects kidney proximal tubule cells from injury induced by triptolide by means of activation of the MEK/ERK pathway. Int J Toxicol. 2009;28(3):177-89. 